\title{
IDENTIFICATION AND MOLECULAR CHARACTERIZATION OF THE INFECTIOUS BURSAL DISEASE VIRUS (IBDV) FROM AN OUTBREAK IN A BROILER FLOCK IN MIDWESTERN BRAZIL
}

\author{
Márcia Beatriz Cardoso de Paula ${ }^{1}$; Jonny Yokosawa ${ }^{2}$; Márcio Danilo Botrel Coutinho ${ }^{3}$; Paulo Lourenço Silva ${ }^{4}$; \\ Rogério Avelar Ferraz ${ }^{3}$; Thelma Fátima Mattos Oliveira ${ }^{1}$; Divina Aparecida Oliveira Queiróz ${ }^{1 *}$
}

${ }^{1}$ Laboratório de Virologia - Instituto de Ciências Biomédicas, Universidade Federal de Uberlândia, Uberlândia, MG, Brasil; ${ }^{2}$ Departamento de Análises Clínicas, Toxicológicas e Bromatológicas, Faculdade de Ciências Farmacêuticas de Ribeirão Preto, Universidade de São Paulo. Ribeirão Preto, SP, Brasil; ${ }^{3}$ Laudo Laboratório Avícola de Uberlândia Ltda, Uberlândia, MG, Brasil; ${ }^{4}$ Faculdade de Medicina Veterinária, Universidade Federal de Uberlândia. Uberlândia, MG, Brasil

Submitted: November 12, 2003; Returned to authors for corrections: July 07, 2004; Approved: October 26, 2004

\begin{abstract}
In order to identify and characterize the agent of a suggestive clinical case of Gumboro disease (GD) that affected a 34-day-old broiler flock in Buriti Alegre (Goias State, Midwestern Brazil) in the year 2001, we carried out a combination of classic and modern virological methods. Histopathological analysis of the bursa revealed necrosis, presence of depleted follicles, some infiltration of heterophils, edema and formation of cystic cavities that are compatible with lesions observed in GD. Inoculation of embryonated eggs of specific pathogen-free (SPF) chickens with macerated bursa suspension resulted in embryo mortality and lesions which were also compatible with those caused by IBDV. A sample of bursa was submitted to a nested reverse transcriptase-polymerase chain reaction (RT-PCR) procedure to amplify the hypervariable region of the VP2 gene. The amplicon that was obtained from this sample (BR-GO) was digested with the restriction enzymes TaqI, StyI and SspI, but not with SacI, a pattern similar to that observed with very virulent IBDV (vvIBDV) strains. Furthermore, nucleotide sequence analysis revealed alanine, isoleucine, and isoleucine at amino acid positions 222, 256, and 294, respectively, which are also found in vvIBDV strains. Finally, phylogenetic analysis grouped BR-GO isolate with other vvIBDV strains.
\end{abstract}

Key words: chicken broiler flock, Gumboro disease, infectious bursal disease virus, IBDV, RT-PCR, molecular characterization

\section{INTRODUCTION}

Infectious bursal disease virus (IBDV) is the causative agent of Gumboro disease (GD), an acute and highly contagious illness affecting young chickens (6). The virus infects and destroys dividing pre-B lymphocytes in the bursa of Fabricius $(12,16)$.

Infectious bursal disease occurs worldwide and few commercial flocks are free of the virus. There are two serotypes of the virus that show minimal cross protection and they can be differentiated by serological assay. Viruses of serotype 1 affect young birds, while viruses of serotype 2 do not seem to be pathogenic or immunosuppressive to chickens $(12,16,18)$.

In the early 1990s, variant strains of serotype 1 virus emerged in the United States, Western Europe and parts of Southeast Asia and that were more virulent than older strains (18). In Europe, these viruses caused mortality rate of over 50\% and were designated as very virulent IBDV strains (vvIBDV). Attempts to control the disease caused by vvIBDV generally have been done by multiple vaccinations with vaccines of different degrees of attenuation prepared from the serotype 1

*Corresponding author. Mailing address: Av. Pará, 1720, Bloco 4C, Campus Umuarama, 38.400-902. Uberlândia - MG, Brasil. Tel.: (+5534) 32182557. Fax: (+5534) 3218-2332. E-mail: dqueiroz@icbim.ufu.br 
virus strain (18). However, in spite of intense vaccinations, the disease caused by vvIBDV strains continues to be a major problem in several parts of the world, causing mortality rate ranging from $3.6 \%$ to $50 \%$, or even higher (24). Furthermore, these strains cause disease even when high levels of antibodies against classical strains are present (18). Although vvIBDV strains are antigenically similar to the other classical strains, they show a very different degree of virulence (21).

Characterization of IBDVs from Latin America revealed that different genotypes were distributed in various countries (1). Very virulent IBDVs were found in Brazil and Dominican Republic.

Histopathological assays allow an easy microscopical visualization of an acute infected bursa and, in association with clinical signs, it has been used for diagnosing GD. In addition, virus isolation has been useful for detecting the presence of IBDV in a clinical sample (16). However, these procedures are time consuming, require intensive labor and cannot identify the serotype or antigenic subtypes of the virus (20). Besides, there are others agents that cause similar bursal lesions (20).

Genome sequencing investigations have been used to characterize IBDV strains molecularly $(1,2)$, allowing analysis of variations that happen naturally or by attenuation in different strains, leading to changes in antigenicity and/or virulence $(4,8,10)$. RT-PCR/RFLP and nucleic acid sequencing of the strain BR-5 (known in Brazil as G11), found in Brazil, revealed that the strain was genotipically similar to vvIBDV strains (1).

IBDV is a $60 \mathrm{~nm}$ nonenveloped virus with icosahedral symmetry, belongs to the Birnaviridae family, and has a genome that has two segments of linear double-stranded RNA $(12,18)$. Segment A has $3.2 \mathrm{~kb}$ and contains two partially overlapping open reading frames (ORFs). The largest ORF encodes for a polyprotein that is proteolytically cleaved to form three polypeptides: VP2 and VP3 are the structural proteins, whereas VP4 is a protease. VP2 contains the major antigenic site, responsible for eliciting neutralizing antibodies (18). Segment B has $2.8 \mathrm{~kb}$ and encodes for VP1, an RNA-dependent RNA polymerase $(16,18)$.

Sequencing of the VP2 hypervariable region, which contains important neutralizing epitopes, has been important to characterize IBDV strains $(7,9,10,23)$, revealing that amino acids alanine, leucine and isoleucine at positions 222, 256 and 294, respectively, are determinant in vvIBDV strains $(3,5,14,19)$.

In this study, we conducted a combination of classic and modern virological techniques in order to identify and characterize the agent from an outbreak that affected a 34-dayold commercial broiler flock in Buriti Alegre (Midwestern Brazil) in the year 2001 .

\section{MATERIALS AND METHODS}

\section{Clinical samples}

Intact bursa of Fabricius with respective peripheral blood mononuclear cell (PBMC) samples were collected from an outbreak in a broiler flock (34-day-old) in the municipality of Buriti Alegre, State of Goias, Midwestern Brazil, that happened in 2001, and transferred to the laboratory in ice and kept at $70^{\circ} \mathrm{C}$. The tissue showed typical signs of infectious bursal disease (IBD) like bursa haemorrhage and presence of a yellow jelly transudation. Histopathological analysis was performed by staining Bursa of Fabricius sections with the hematoxylin/ eosin method.

\section{Virus isolation}

One bursa of Fabricius was ground and a 10\% suspension was prepared in TPB (Tryptose Phosphate Broth, Difco Laboratories - Franklin Lakes, NJ) with $1 \mathrm{mg} / \mathrm{mL}$ of streptomycin sulphate (INLAB - Brazil), $0.4 \mathrm{mg} / \mathrm{mL}$ of gentamicin sulphate (Schering Plough - Kenilworth, NJ) and $1000 \mathrm{UI} / \mathrm{mL}$ of penicillin (Ariston - Sao Paulo, Brazil). Fifteen 11-day-old SPF eggs were inoculated with $0.1 \mathrm{~mL}$ of the suspension via the chorioallantoic membrane (CAM) route and observed daily.

\section{RNA extraction}

Total RNA was extracted from $0.5 \mathrm{mg}$ of bursa and PBMCs (number of cells was not determined) from the infected birds with TriPure Isolation Reagent (Roche Molecular Biochemicals, Indianapolis, IN). Thin slices of bursa tissue and PBMCs were transferred to Eppendorf tubes and homogenized with Tripure according to the manufacturer's instructions. After addition of chloroform and centrifugation, the aqueous phase was transferred to another tube and total RNA was precipitated with isopropyl alcohol. RNA pellet was dissolved in $11 \mu \mathrm{l}$ of DEPCtreated water (Ambion, Inc. Austin, TX).

\section{Reverse transcription and nested-polymerase chain reaction (nested-PCR)}

For the amplification of the hypervariable region of VP2 gene by PCR, two $\mu$ l of total RNA was reverse transcribed into cDNA with the following conditions: $0.5 \mu \mathrm{M}$ primer $\mathrm{P} 2,0.25 \mathrm{mM}$ of each deoxyribonucleotide (Roche), 20 units of ribonuclease inhibitor (Roche), 40 units of M-MuLV reverse transcriptase (Roche) and buffer provided by the manufacturer in a total volume of $20 \mu \mathrm{L}$. The reaction was carried out at $37^{\circ} \mathrm{C}$ for $60 \mathrm{~min}$ and stopped by incubation at $95^{\circ} \mathrm{C}$ for $10 \mathrm{~min}$. Five $\mu 1$ of cDNA sample was submitted to the first round PCR with oligonucleotides P1 and P2 described by Liu et al. (13). For the second round described by Chen et al. (4) with modifications were used: primer P3, 5'-GCCCAGAGTCTACACCATAACT and primer P4, 5'-GCGACCGTAACGACGG ATCC. The following reaction conditions were carried out: $0.2 \mathrm{mM}$ of each deoxyribonucleotide triphosphate, $0.3 \mu \mathrm{M}$ of primers $\mathrm{P} 1$ and $\mathrm{P} 2$ (or primers $\mathrm{P} 3$ and $\mathrm{P} 4$ for the nested PCR), 2.5 units of Taq DNA polymerase (Roche) and supplied buffer (final concentration of buffer was $10 \mathrm{mM}$ Tris- $\mathrm{HCl}, 1.5 \mathrm{mM} \mathrm{MgCl}_{2}, 50 \mathrm{mM} \mathrm{KCl}, \mathrm{pH} 8.3$ ) in a total volume of $50 \mu \mathrm{l}$. Two microliter of the first round reaction 
was pipetted into the second round reaction tube. The reactions were carried out as follows: $94^{\circ} \mathrm{C}$ for $10 \mathrm{~min}$, followed by 40 cycles (or 30 cycles for the nested reaction) at $94^{\circ} \mathrm{C}$ for $45 \mathrm{~s}, 50^{\circ} \mathrm{C}$ for $30 \mathrm{~s}$ and $72^{\circ} \mathrm{C}$ for $1 \mathrm{~min}$, and a final extension step of $72^{\circ} \mathrm{C}$ for $5 \mathrm{~min}$. Five microliter of the second round PCR product was separated on a $1 \%$ agarose gel stained with $0.3 \mu \mathrm{g} / \mathrm{ml}$ ethidium bromide.

\section{Restriction enzyme digestion}

PCR products were purified with QIAquick PCR purification Kit (QIAgen Inc. Valencia, CA) and digested with the enzymes DraI, SacI, MvaI, TaqI, StyI and SspI (7). The restriction fragments were separated on a $2 \%$ agarose gel stained with ethidium bromide.

\section{Sequencing and sequence analyses}

Purified PCR product was sequenced by cycle sequencing by using second round primers with BigDye Terminator and ABI PRISM 377 sequencer (Applied Biosystems. Foster City, CA). Sequence data was assembled and analysed with Seqman and MegAlign (DNAStar Inc. Madison, WI). Phylogenetic analysis of $432 \mathrm{bp}$ sequence containing the hypervariable region of VP2 gene, from nucleotide 759 to 1190 (numbering according to Bayliss et al. (8)), was performed by the Neighbor-Joining method and 1000 bootstrap replicates with MEGA version 2.1 (11). The nucleotide sequence of BR-GO was deposited at GenBank under accession number AY423560. The following IDBV strain sequences (accession numbers) were used in the analyses: vvIBDV strains - DV86(D16630), OKYM (D49706), UK661 (X92760), HK46 (AF092943), DR-2 (AF498626), and BR5 (AF498624); classical and variant strains - 002-73 (X03993), STC (D00499), 52/70 (D00869), GLS (M97346), P2 (X84034), Cu1 (D00867), Variant A(M64285), and Variant E(D10065).

\section{RESULTS AND DISCUSSION}

\section{Histopathological analysis}

Bursa of Fabricius from diseased birds with typical signs of infectious bursitis showed presence of cysts, lymphoid follicles hypo trophy, necrosis and heterophils invasion (Fig. 1). The association of the broiler flock clinical signs like bursal haemorrhage, presence of transudation over the bursa, with the hystopathological results and with a poor performance in terms of gain of body weight, observed at slaughterhouses, suggested that the disease was caused by IBDV.

\section{Virus isolation}

Considering that several viruses have a specific tropism for lymphoid tissues (20), the isolation in SPF eggs was performed in order to obtain a more conclusive indication of the agent. Inoculation of a suspension of macerated bursa into 15 eggs produced embryo mortality 2-4 days after the inoculation.
Embryos presented edematous distension of the abdominal region and cutaneous congestion (data not shown). Two embryos were still alive on the fourth day and we observed lesions in their livers and muscular dystrophy, which are clear signs of Gumboro disease (16).
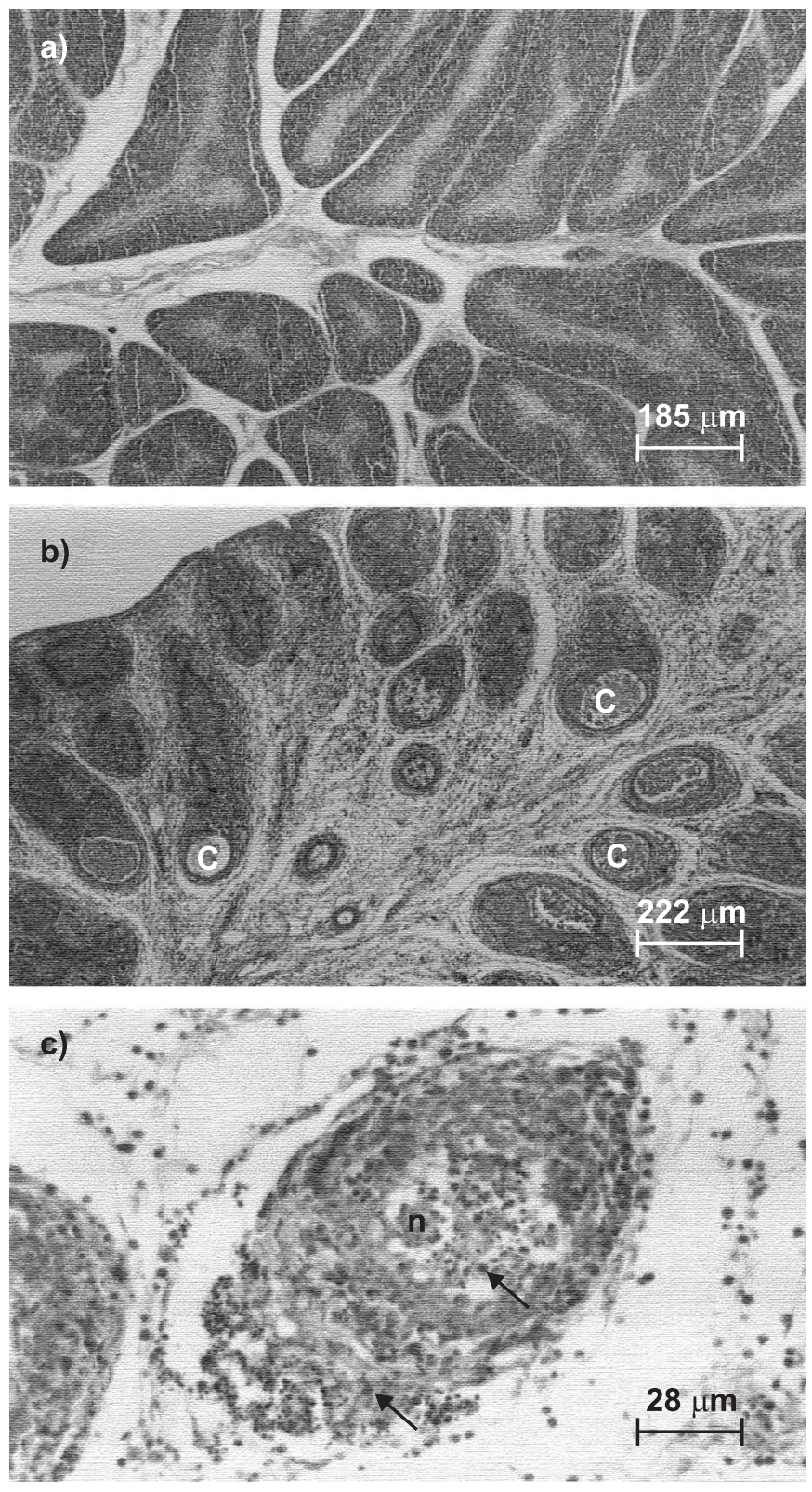

Figure 1. Bursal tissue section stained with hematoxylin and eosin (H\&E). a) Normal lymphoid follicles; b) Bursa with infectious bursitis presenting cysts (c) and lymphoid follicles hypotrophy; c) Bursa with infectious bursitis presenting necrosis (n) and heterophils invasion (arrow). 


\section{Detection of viral RNA by RT-PCR and restriction enzyme digestion analysis}

The two-round amplification reaction was used to amplify a 492 bp fragment, from nucleotide position 737 to 1228 (numbering according to Bayliss et al. (2)) of the hypervariable region of the VP2 gene (Fig. 2a) and allowed us to reach a definite conclusion of the causative agent of the outbreak. The amplicon obtained from a bursa sample was purified and digested with a set of restriction endonucleases. Sites for the enzymes $M v a \mathrm{I}, T a q \mathrm{I}, S s p \mathrm{I}$ and $S t y \mathrm{I}$ were present in the fragment, whereas sites for SacI and DraI were not (Fig. 2b). SacI site is present only in classical virulent strain (23), whereas TaqI, SspI and StyI sites are present in vvIBDV strains $(7,10,15)$. The restriction site for $M v a \mathrm{I}$ present in the amplicon is located outside the sequence reported by Ikuta et al. (7), as revealed by sequencing. Thus, the pattern obtained with BR-GO corresponded to the RFLP pattern 11, which is described by those authors as a pattern shown by vvIBDV strains and is known as G11.

a)

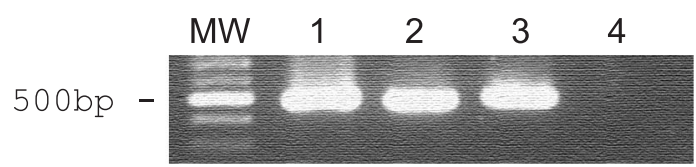

b)

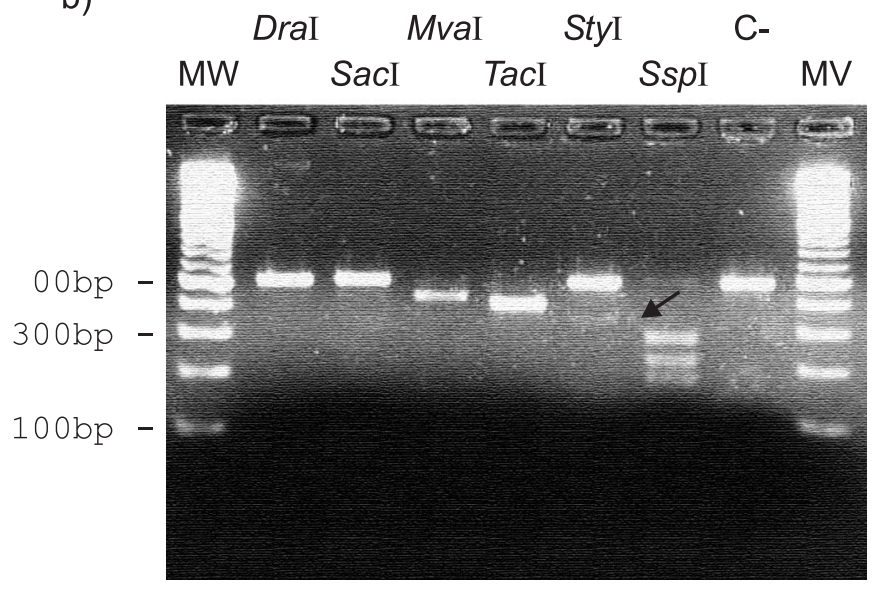

Figure 2. a) Detection of IBDV RNA by nested RT-PCR assay: MW - 100bp molecular weight marker (Roche); amplification reaction carried out with two different bursa samples (1 and 2), macerated embryos from virus isolation (3) and negative control (4). b) Electrophoresis of PCR product digested with restriction endonucleases indicated. C- indicates the reaction without any enzyme, whilst digestion occurred with MvaI, TaqI, StyI and SspI. The arrow indicates result of partial digestion with StyI, although the manufacturer's instructions were followed and two different lots of the enzyme were used.

\section{Sequence analyses}

Sequence analysis and comparison of $432 \mathrm{bp}$ containing the hypervariable region of VP2 with various strains revealed that BR-GO had the highest nucleotide identity with vvIBDV strains (Table 1), ranging from 98.6 to $99.8 \%$. On the other hand, identity ranged from 84.8 to $94.7 \%$ with classical and variant strains. Furthermore, amino acid sequence identity was also higher with vvIBDV (99.3-100.0\%) strains than with classical or variant strains (91.0-97.2\%). Although BR-5 strain was also found in Brazil (1), BR-GO had lower nucleotide and amino acid identities with this strain than to the vvIBDV strains found in other countries. DR-2, a vvIBDV strain found in Dominican Republic (1), had an even lower nucleotide identity. BR-GO strain, on the other hand, had higher nucleotide identity with DV-86, a strain found in Japan (22). Sequence analysis also revealed that there were no deletions or insertions in the obtained sequence of hypervariable region of $\mathrm{BR}-\mathrm{GO}$ strain compared to the consensus sequence of various strains.

Although SspI, TaqI and StyI sites are present in vvIBDV strains, $S s p$ I is the only site that corresponds to an amino acid substitution, from leucine to isoleucine at position 294, in comparison with non vvIDBV strains. This substitution was also observed in BR-GO sequence. Alanine at position 222 and isoleucine at position 256, which are characteristic of vVIBDV strains, were also present in BR-GO sequence (Fig. 3). Isoleucine and serine at positions 242 and 299, respectively, were observed in BR-GO strain. However, they have not been observed exclusively in vVIBDV strains (5). Despite the nucleotide identity differences with strains found in Latin American

Table 1. Nucleotide and amino acid identities of the hypervariable region of ORF2 among BR-GO and other IBDV strains.

\begin{tabular}{lcc}
\hline & \multicolumn{2}{c}{ Identity $(\%)$} \\
\cline { 2 - 3 } & Nucleotide & Amino acid \\
\hline BR-5 & 98.6 & 99.3 \\
DV86 & 99.8 & 100.0 \\
HK46 & 99.3 & 100.0 \\
OKYM & 99.3 & 100.0 \\
UK661 & 99.1 & 100.0 \\
DR-2 & 97.0 & 99.3 \\
O02-73 & 84.8 & 91.0 \\
STC & 93.9 & 94.4 \\
52-70 & 94.7 & 97.2 \\
Cu1 & 92.1 & 92.4 \\
P2 & 92.6 & 92.4 \\
GLS & 92.4 & 91.7 \\
Var-A & 92.6 & 93.1 \\
Var-E & 92.3 & 91.7 \\
\hline
\end{tabular}




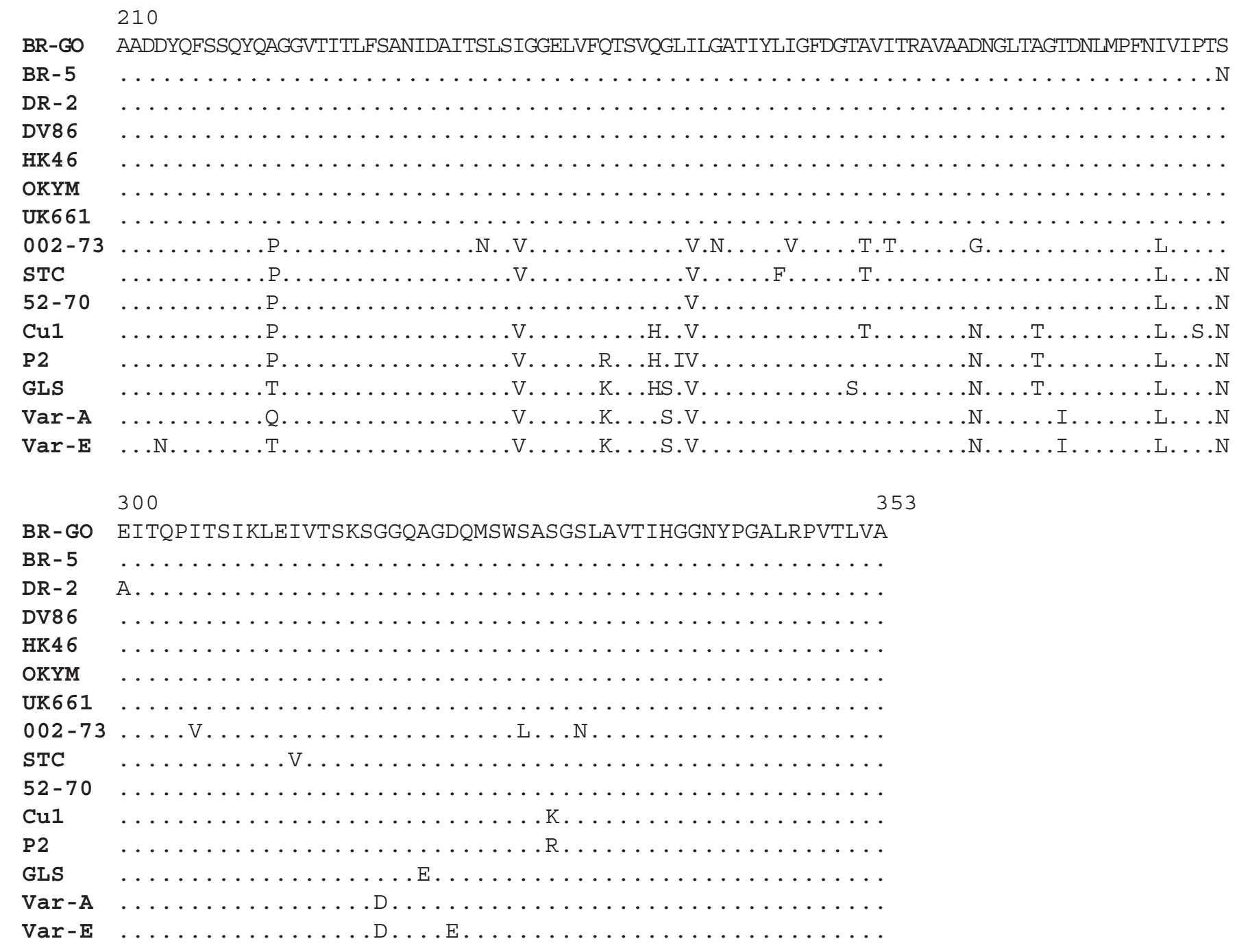

Figure 3. Alignment and comparison of deduced amino acid sequences (numbering according to Bayliss et al., 1990) of the hypervariable region of ORF2 of very virulent strains (BR-5, DV86, HK46, OKYM, and UK661) and non-very virulent serotype 1 strains (002-73, STC, 52-70, Cu1, P2, GLS, Var-A, and Var-E). Amino acid differences with respect to the BR-GO strain are shown and identical amino acid residue is indicated with a dot.

countries, there was only one amino acid changed, an asparagine to serine substitution at position 299 , when compared to BR-5 and another one, an alanine to glutamic acid substitution at position 300, with DR-2. These differences, however, do not seem to be related to pathogenicity of these strains, as suggested by Chong et al. (5), although serine at position 299 was present in many vvIBDV strains.

Results from the phylogenetic tree analysis based on the $432 \mathrm{bp}$ sequence indicated that the BR-GO strain was most closely related to other vvIBDV strains, forming a group clearly distinguishable from other less virulent strains (Fig. 4).
Although classic virological techniques combined with observation of clinical signs in most cases lead to the identification of IBDV as the causative agent of an avian disease, other agents might cause diseases with similar signs. In addition, they are time consuming and require intensive labor. In our study, a correct identification was obtained with nested RT-PCR, a modern method of diagnostic. Furthermore, with the use of RFLP assay we characterized the agent as being a vvIBDV strain, which was confirmed by analyses of the BR-GO sequence. In conclusion, RTPCR combined with RFLP could be used for a rapid detection and characterization of the virus directly from bursa or PBMC samples. 


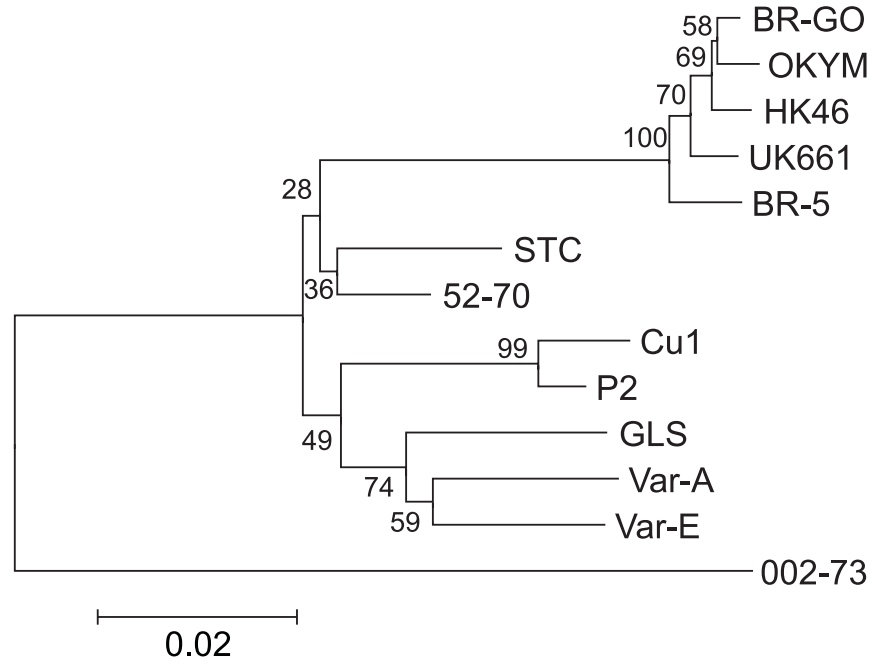

Figure 4. Phylogenetic tree based on the nucleotide sequence of the hypervariable region of ORF2 of the BR-GO, very virulent (BR-5, DV86, HK46, OKYM, and UK661) and non-very virulent serotype 1 strains (002-73, STC, 52-70, Cu1, P2, GLS, Var-A, and Var-E). Tree was constructed by the Neighbor-Joining method. Bootstrap probabilities (\%) are given beside the node.

\section{ACKNOWLEDGEMENTS}

Márcia B. C. de Paula was sponsored by the Conselho Nacional de Desenvolvimento Científico e Tecnológico (CNPq, Brazil) while obtaining her master degree at Programa de PósGraduação em Imunologia e Parasitologia Aplicadas at Universidade Federal de Uberlândia (UFU). We thank Drs. Humberto Eustáquio Coelho and Marcelo Beletti from Faculdade de Medicina Veterinária (UFU), for assisting with histological determinations, Área de Ciências Fisiológicas and Laboratório de Genética Molecular (UFU), Dr. Márcia Cristina Cury from Laboratório de Parasitologia (UFU), and Prof. Maria Raquel Carvalho from Departamento de Patologia, Instituto de Ciências Biológicas at Universidade Federal de Minas Gerais (UFMG) for providing their help.

\section{RESUMO}

\section{Identificação e caracterização molecular do vírus da doença infecciosa da bolsa cloacal de um surto em lotes de frangos no centro-oeste do Brasil}

Para identificar e caracterizar o agente causador de um quadro clínico sugestivo de doença de Gumboro (DG) que afetou um plantel de frangos de corte com 34 dias de idade, em Buriti Alegre (estado de Goiás, centro-oeste do Brasil), no ano de
2001, procedeu-se uma combinação de métodos virológicos clássicos e modernos. Análises histopatológicas de bursas revelaram necrose, depleção de folículos linfóides, infiltração de heterófilos, edema e formação de cistos, lesões compatíveis com DG. A inoculação em ovos embrionados de galinhas SPF (specific pathogen-free) de uma suspensão de macerado de amostras de bursas resultou em mortalidade embrionária e lesões macroscópicas compatíveis com aquelas provocadas pelo VDIB. Amostras de bursas foram submetidas à técnica de transcrição reversa-reação em cadeia da polimerase (RT-PCR), utilizandose oligonucleotídeos específicos para amplificação da região hipervariável do gene da VP2. Essa reação produziu um fragmento do tamanho esperado, que foi digerido pelas enzimas de restrição TaqI, StyI e SspI, mas não foi digerido com SacI. Este padrão foi o mesmo observado com cepas de VDIB hipervirulentas (vvVDIB). Análise da seqüência nucleotídica revelou a presença dos aminoácidos alanina, isoleucina e isoleucina nas posições 222, 256 e 294, respectivamente, característica dessas cepas. Além disso, análise filogenética realizada agrupou a cepa encontrada, denominada de BR-GO, com outras cepas de vvVDIB.

Palavras-chave: dença de Gumboro, vírus da doença infecciosa da bolsa cloacal, VDIB, galinhas, RT-PCR e caracterização molecular

\section{REFERENCES}

1. Banda, A.; Villegas, P.; El-Attrache, J. Molecular characterization of infectious bursal disease virus from commercial poultry in the United States and Latin America. Avian Dis., 47:87-95, 2003.

2. Bayliss, C.D.; Spies, U.; Shaw, K.; Peters, R.W.; Papageorgiou, A.; Müller, H.; Boursnell, M.E.G. A comparison of the sequences of segment A of four infectious bursal disease virus strains and identification of a variable region in VP2. J. Gen. Virol., 71:13031312, 1990.

3. Cao, Y.C.; Yeung, W.S.; Law, M.; Bi, Y.Z.; Leung, F.C.; Lim, B.L. Molecular characterization of seven Chinese isolates of infectious bursal disease virus: classical, very virulent, and variant strains. Avian Dis., 42:340-351, 1998.

4. Chen, H.Y.; Zhou, Q.; Zhang, M.F.; Giambrone, J.J. Sequence analysis of the VP2 hypervariable region of nine infectious bursal disease virus isolates from mainland China. Avian Dis., 42:762-769, 1998.

5. Chong, L.K.; Omar, A.R.; Yusoff, K.; Hair-Bejo, M.; Aini, I. Nucleotide sequence and phylogenetic analysis of A segment of a highly virulent strain of infectious bursal disease virus. Acta virol., 45:217-226, 2001.

6. Cosgrove, A.S. An apparently new disease of chickens - avian nephrosis. Avian Dis., 6:385-389, 1962.

7. Ikuta, N.; El-Attrache, J.; Villegas, P.; García, M.; Lunge, V.R.; Fonseca, A.S.K.; Oliveira, C.; Marques, E.K. Molecular characterization of Brazilian infectious bursal disease virus. Avian Dis., 45:297-306, 2001 .

8. Jackwood, D.J.; Jackwood, R.J. Infectious bursal disease viruses: molecular differentiation of antigenic subtypes among serotype 1 viruses. Avian Dis., 38:531-537, 1994.

9. Jackwood, D.J.; Sommer, S.E. Restriction fragment length polymorphism in the VP2 gene of infectious bursal disease viruses from outside the United States. Avian Dis., 43:310-314, 1999. 
10. Jackwood, D.J.; Sommer, S.E.; Knoblike, H.V. Amino acid comparison of infectious bursal disease viruses placed in the same or different molecular groups by RT/PCR-RFLP. Avian Dis., 45:330-339, 2001.

11. Kumar, S.; Tamura, K.; Jakobsen, I.B.; Nei, M. MEGA2: Molecular Evolutionary Genetics Analysis software, Arizona State University, Tempe, Arizona, USA, 2001.

12. Lasher, H.N.; Shane, S.M. Infectious Bursal Disease. Poult. Sci., 50:133-166, 1994

13. Liu, H.; Giambrone, J.J.; Dormitorio, T. Detection of genetic variations in serotype I isolates of infectious bursal disease virus using polymerase chain reaction and restriction endonuclease analysis. J. Virol. Methods, 48:281-291, 1994.

14. Liu, H.J.; Huang, P.H.; Wu, Y.H.; Lin, M.Y.; Liao, M.H. Molecular characterisation of very virulent infectious bursal disease viruses in Taiwan. Res. Vet. Sci., 70:139-147, 2001.

15. Lojki, I.; Bidin, Z.; Pokri, B. Differentiation of Infectious Bursal Disease Viruses Isolated in Croatia. Avian Dis., 47:59-65, 2003.

16. Lukert, P.D.; Saif, Y.M. Infectious Bursal Disease. In: Diseases of Poultry, $10^{\text {th }}$ edition - B.W. Calnek. (ed.). Iowa State University Press, Ames, 1997, p.721-738.

17. McFerran, J.B.; McNulty, M.S.; McKillop, E.R.; Connor, T.J.; McCracken, R.M.; Collins, D.S.; Allan, G.M. Isolation and serological studies with infectious bursal disease viruses from fowl, turkeys and ducks: demonstration of a second serotype. Avian Pathol., 9:395404, 1980.

18. Murphy, F.A.; Gibbs, E.P.J.; Horzinek, M.C.; Studdert, M.J. (eds.). Birnaviridae. In: Veterinary Virology, $3^{\text {rd }}$ edition. Academic Press. Orlando, 1999, p.405-409.

19. Phong, S.F.; Hair-Bejo, M.; Omar, A.R.; Aini, I. Sequence analysis of Malaysian infectious bursal disease viruse isolate and the use of reverse transcriptase nested polymerase chain reaction enzyme-linked immunosorbent assay for the detection of VP2 hypervariable region. Avian Dis., 47:154-162, 2003.

20. Riddell, C. (ed.) Lymphoid System. In: Avian Histopathology. American Association of Avian Pathologists. Athens, 1987, p.8-14.

21. Van den Berg, T.P.; Meulemans, G. Acute infectious bursal disease in poultry: protection afforded by maternally derived antibodies and interference with live vaccination. Avian Pathol., 20:409-421, 1991.

22. Yamaguchi, T.; Ogawa, M.; Inoshima, Y.; Miyoshi, M.; Fukushi, H.; Hirai, K. Identification of sequence changes responsible for the attenuation of highly virulent infectious bursal disease virus. Virology, 223(1):219-223, 1996.

23. Zierenberg, K.; Raue, R.; Muller, H. Rapid identification of "very virulent" strains of infectious bursal disease virus by reverse transcription-polymerase chain reaction combined with restriction enzyme analysis. Avian Pathol., 30:55-62, 2001. 